\title{
INTRODUKSI TEKNIK PEMBENIHAN BANDENG SKALA RUMAH TANGGA DI DESA PIJOT KECAMATAN KERUAK KABUPATEN LOMBOK TIMUR
}

\author{
Nunik Cokrowati ${ }^{1 *}$, Alis Mukhlis ${ }^{1)}$ \\ ${ }^{1)}$ Program Studi Budidaya Perairan, Universitas Mataram. \\ Jl. Majapahit No. 62 Mataram, 83125 \\ *korespondensi: nunikcokrowati@unram.ac.id
}

\begin{abstract}
ABSTRAK
Kegiatan ini bertujuan untuk mengintroduksi teknologi pembenihan bandeng. Manfaat dari kegiatan ini adalah masyarakat dapat melakukan pembenihan bandeng dan dapat memproduksi benih bandeng atau nener untuk kepentingan benih budidayanya sendiri. Metode pelaksanaan kegiatan ini adalah memberikan pelatihan langsung teknik pembenihan bandeng dengan tahapan penentuan kelompok mitra, sosialisasi kegiatan, introduksi teknologi budidaya bandeng daan pembimbingan. Benih bandeng atau nener di Nusa Tenggara Barat, tidak mudah didapatkan dan mahal. Hal tersebut dikarenakan nener didatangkan dari pulau Jawa dan jumlahnya juga terbatas. Masyarakat belum dapat melakukan pembenihan bandeng dikarenakan belum pernah diajari hal tersebut. Teknologi pembenihan bandeng cukup sederhana dan dapat dilakukan dengan mudah, murah dan efisen. Sehingga teknologi pembenihan bandeng perlu diajarkan ke masyarakat. Mitra kegiatan ini adalah pembudidaya bandeng di Desa Pijot kecamatan Jerowaru Kabupaten Lombok Timur.
\end{abstract}

Kata kunci:alami,bandeng, buatan, budidaya, nener, pembenihan

\section{PENDAHULUAN}

Bandeng (Chanos chanos) merupakan ikan penyumbang produksi paling banyak terhadap kegiatan budidaya perairan. Pada tahun 2008 secara nasional, produksi Chanos chanos adalah 550 ribu ton dan pada tahun 2009 mengalami peningkatan 41,15\%. Chanos chanos memiliki keunggulan komparatif dan strategis dibanding komoditas perikanan yang lain yaitu (1) Teknologi pembesaran dan pembenihannya telah dikuasai dan berkembang di masyarakat, (2) Persyaratan hidupnya tidak menuntut kriteria kelayakan yang tinggi mengingat bandeng toleran terhadap perubahan mutu lingkungan serta tahan terhadap serangan penyakit, (3) merupakan ikan yang paling banyak diproduksi di Indonesia dalam bentuk hidup sebagai umpan dalam usaha penangkapan ikan tuna dan cakalang, (4) merupakan sumber protein yang potensial bagi pemenuhan gizi serta pendapatan masyarakat petambak dan nelayan dan (5) telah menjadi komoditas ekspor. Bandeng diproduksi dalam berbagai ukuran, disesuaikan dengan kebutuhan penggunaannya seperti umpan dalam usaha penangkapan tuna dan cakalang, untuk dikonsumsi langsung, untuk ekspor dan untuk induk (Kordi, 2009).

$$
\text { Budidaya bandeng di Nusa }
$$

Tenggara Barat diantaranya di Pulau Lombok, belum banyak dilakukan. Masyarakat membudidayakan Bandeng pada tambak tradisional dan skala kecil. Pada umumnya budidaya bandeng dilakukan sebagai usaha sampingan dari budidaya udang, sehingga produksi 
bandeng tidak banyak di pulau Lombok. Mulai tahun 2014, minat konsumsi bandeng di Lombok mulai meningkat. Hal tersebut terlihat dari semakin meningkatnya jumlah produksi bandeng dan peningkatan konsumsinya. Di pasar tradisional, mulai terjadi peningkatan jumlah penjual dan penjualan bandeng. Hal tersebut memicu minat masyarakat untuk melakukan budidaya bandeng. Namun permasalahnya adalah bibit bandeng atau nener tidak dapat dengan mudah dibeli di Lombok maupun Sumbawa. Nener sangat terbatas, diperoleh dari tangkapan alam. Belum ada usaha pembenihan bandeng, sehingga nener sebagian besar didatangkan dari Jawa. Sehingga harga nener menjadi mahal dan harus menunggu pasokan dari Jawa. Sehingga diperlukan keterampilan pembenihan bandeng bagi pembudidaya, untuk mengurangi biaya produksi budidaya bandeng. Teknologi pembenihan bandeng sudah ada dan dapat dengan mudah dilakukan oleh pembudidaya serta tidak memerlukan biaya yang mahal. Sehingga melalui kegiatan pengabdian kepada masyarakat, Program Studi Budidaya Perairan Unram melakukan transfer teknologi pembenihan bandeng kepada masyarakat Desa Pijot Kecamatan Keruak Kabupaten Lombok Timur.

\section{METODE KEGIATAN}

Kegiatan ini dilaksanakan pada bulan Desember 2017 di Desa Pijot Kecamatan Keruak Kabupaten Lombok Timur. Mitra kegiatan ini adalah pembudidaya bandeng yang ada di desa tersebut sejumlah 25 orang. Introduksi teknik pembenihan bandeng dilakukan dengan metode penyuluhan dan diskusi langsung dengan pembudidaya bandeng. Teknik pembenihan bandeng dijelaskan secara teori dan pemutaran video teknik pembenihan bandeng.

\section{HASIL DAN PEMBAHASAN}

Pembenihan bandeng dapat dilakukan dengan secara alami dan secara buatan. Teknik pembenihan secara alami dilakukan dengan cara sebagai berikut.

1. Ukuran bak induk 30-100 ton dengan kedalaman 1,5-3,0 meter berbentuk bulat dengan dilengkapi aerasi kuat menggunakan "diffuser" sampai dasar bak serta ditutup dengan jaring.

2. Pergantian air minimal $150 \%$ setiap hari.

3. Kepadatan tidak lebih dari satu induk per 2-4 per meter kubik air.

4. Pemijahan umumnya pada malam hari. Induk jantan mengeluarkan sperma dan induk betina mengeluarkan telur sehingga fertilisasi terjadi eksternal.

Pembenihan secara buatan dilakukan dengan teknik sebagai berikut;

\section{Teknik pembenihan buatan}

1. Pembenihan buatan dilakukan dengan melakukan perangsangan buatan menggunakan hormonal. Hormon berbentuk cair diberikan pada saat induk jantan dan betina sudah matang gonad sedang hormon berbentuk padat diberikan setiap bulan (implantasi).

2. Induk bandeng akan memijah setelah 215 kali implantasi tergantung dari tingkat kematangan gonad. Hormon yang digunakan untuk implantasi biasanya LHRH-a dan 17 alpha methyltestoterone pada dosis masingmasing 100-200 mikron per ekor induk (>4 Kg beratnya).

3. Pemijahan induk betina yang mengandung telur berdiameter lebih dari 750 mikron atau induk jantan yang mengandung sperma tingkat tiga dapat dipercepat dengan penyuntikan hormon LHRH-a pada dosis 5.000-10.000 IU per Kg berat tubuh.

4. Volume bak 10-20 kedalaman 1,5-30 meter berbentuk bulat terbuat dari serat kaca atau beton ditutup dengan jaring 
dihindarkan dari kilasan cahaya pada malam hari untuk mencegah induk meloncat keluar tangki.

Kegiatan penyuluhan dilaksanakan pada tanggal 13 Desember 2017 di salah satu rumah pembudidaya Bandeng di Desa Pijot Kecamatan Keruak Kabupaten Lombok Timur. Kegiatan ini diikuti oleh 25 orang pembudidaya. Berikut gambar kegiatan penyuluhan.

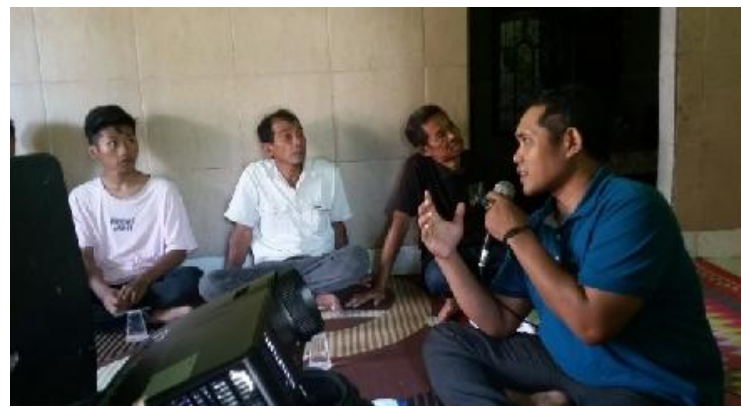

Gambar 1. Pemateri Penyuluhan

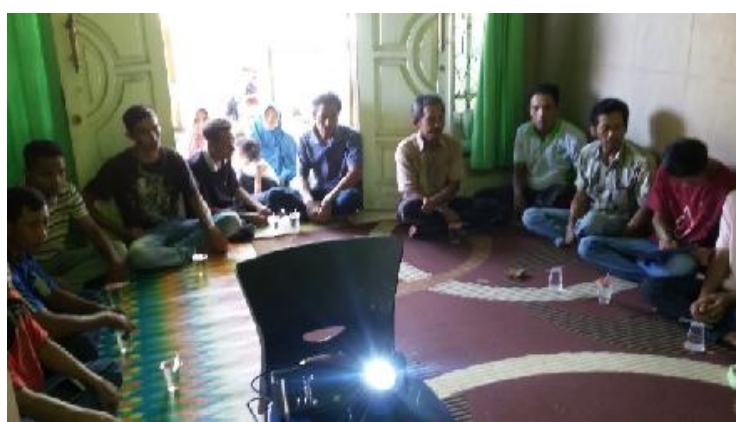

Gambar 2. Pembudidaya bandeng sebagai peserta penyuluhan

Pada kegiatan ini, dijelaskan secara detail teknik pembenihan bandeng skala rumah tangga. Pembudidaya antusias ingin memiliki keterampilan pembenihan bandeng untuk memenuhi kebutuhan bibit bandeng di kalangan mereka sendiri. Tambak yang mereka kelola adalah tambak tradisional sebagaimana gambar berikut.

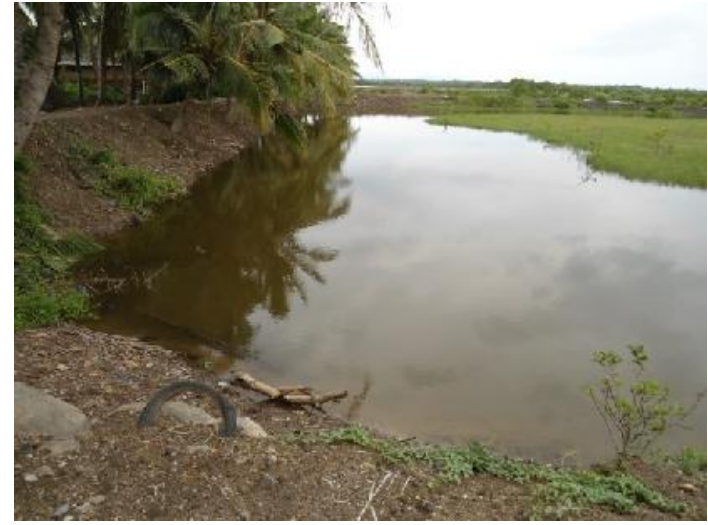

Gambar 3. Tambak tradisional milik pembudidaya

Pembudidaya melakukan pembesaran bandeng secara tradisional. Bibit bandeng mereka peroleh dari alam dan terkadang mereka beli di luar pulau Lombok. Seringkali pembudidaya mengalami kesulitan memperoleh bibit bandeng. Bandeng hasil budidaya yang mereka lakukan, dipasarkan di sekitar Lombok Timur dan Kota Mataram.

\section{KESIMPULAN DAN SARAN}

Teknik pembenihan bandeng skala rumah tangga dapat menambah keterampilan teknis bagi pembudidaya bandeng di Desa Pijot Kecamatan Keruak dan dapat memberikan sumbangsih pemecahan masalah dalam mendapatkan benih bandeng.

\section{DAFTAR PUSTAKA}

Kordi, K., M. Ghufran, 2009. Sukses memproduksi Bandeng Super Untuk Umpan, Ekspor,\& Indukan. Lily Publisher. Yogyakarta.

Saputra, Dadang, 2009. Peluang Usaha Pakan Ikan Alami. Penerbit Titian Ilmu Bandung. Bandung. 
Wibowo, S., Bagus, S., T.H. Suryaningrum, dan Syamdidi, 2013. Artemia Untuk Pakan Ikan dan Udang. Penerbit Penebar Swadaya. Jakarta. 